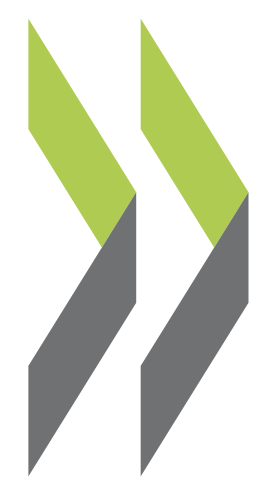

OECD Economics Department Working Papers No. 638

Improving the Business and Investment Climate Diego Moccero

in Indonesia 
Organisation de Coopération et de Développement Économiques

Organisation for Economic Co-operation and Development

23-Sep-2008

ECONOMICS DEPARTMENT

English - Or. English

IMPROVING THE BUSINESS AND INVESTMENT CLIMATE IN INDONESIA

ECONOMICS DEPARTMENT WORKING PAPER No. 638

By Diego Moccero

All OECD Economics Department Working Papers are available on the OECD internet website at www.oecd.org/eco/working_papers 


\section{ABSTRACT/RESUME}

\section{Improving the business and investment climate in Indonesia}

Indonesia's business environment is discouraging entrepreneurship and holding back private-sector growth and development. Weaknesses in the regulatory framework, infrastructure bottlenecks and poor governance continue to weigh down on investment. Policies have been put in place to address these problems, but much remains to be done. An important recent initiative is the enactment of the Investment Law in 2007, which strengthened the foreign investment regime. This paper argues that options for reform could focus on making regulations more pro-business, including by removing red tape and onerous provisions at the local level of government, improving governance and relaxing remaining restrictions on foreign investment. Further financial deepening would facilitate access by enterprises to more abundant, cheaper sources of finance. This Working Paper relates to the 2008 OECD Economic Assessment of Indonesia (www.oecd.org/eco/surveys/indonesia).

JEL codes: E22; F21; G20.

Keywords: Indonesia; investment climate; foreign direct investment; infrastructure; financial sector.

$* * * * *$

\section{Améliorer le cadre des affaires et des investissements en Indonésie}

En Indonésie, le cadre des affaires décourage la création d'entreprises et freine la croissance du secteur privé. Les faiblesses de la réglementation, les goulets d'étranglement dans les infrastructures et la médiocrité de la gouvernance continuent à entraver les investissements. Des mesures ont été prises pour remédier à ces problèmes, mais beaucoup reste à faire. L'une des importantes initiatives prises récemment a été l'adoption, en 2007, d'une loi sur les investissements qui a amélioré le régime des investissements étrangers. On soutient dans ce papier que la réforme pourrait viser surtout à rendre la réglementation plus favorable à l'activité privée, notamment en supprimant les tracasseries et les lourdeurs administratives aux échelons locaux des pouvoirs publics, en améliorant la gouvernance et en assouplissant les restrictions qui subsistent à l'égard des investissements étrangers. En outre, la poursuite de l'approfondissement des marchés financiers permettrait aux entreprises de se procurer davantage de fonds à moindre coût. Ce Document de travail se rapporte à l'Évaluation économique de l'OCDE de l'Indonesie, 2008 (www.oecd.org/eco/etudes/indonesie).

Classification JEL : E22; F21; G20.

Mots-clés: Indonésie; climat des affaires; investissement directe étranger; infrastructure; secteur financier.

Copyright (C) OECD, 2008. All rights reserved. Application for permission to reproduce or translate all, or part of, this material should be made to: Head of Publications Service, OECD, 2 rue André-Pascal, 75775 PARIS CEDEX 16, France. 


\section{TABLE OF CONTENTS}

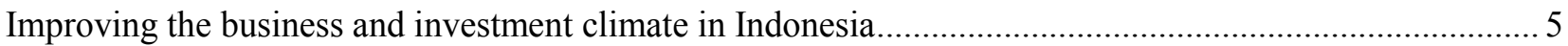

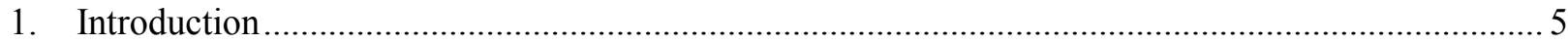

2. Trends in investment and an assessment of the business climate ................................................ 5

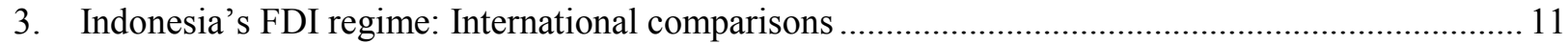

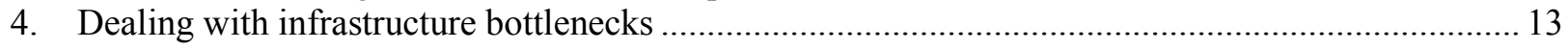

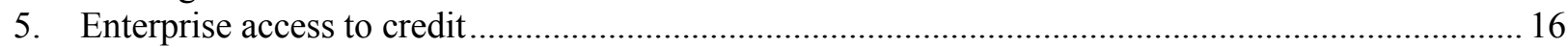

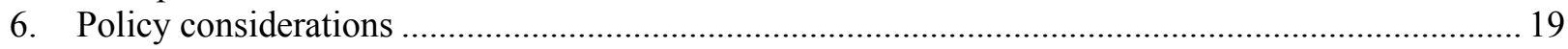

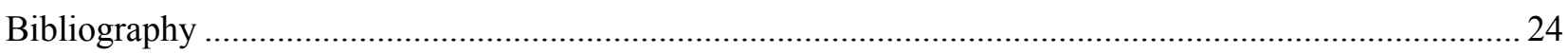

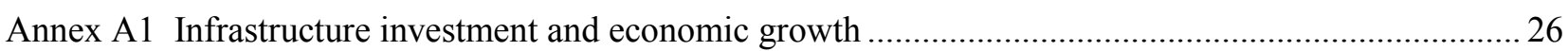

Annex A2 Enterprise expenditure on royalties, $R \& D$ and labour training: Firm-level evidence................ 28

\section{Boxes}

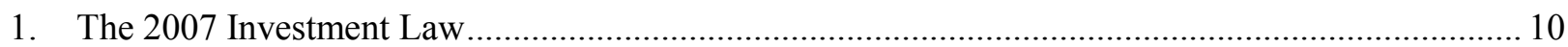

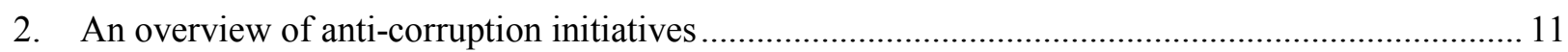

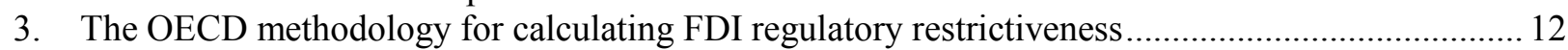

4. Efforts to encourage private-sector involvement in infrastructure development .............................. 16

\section{Tables}

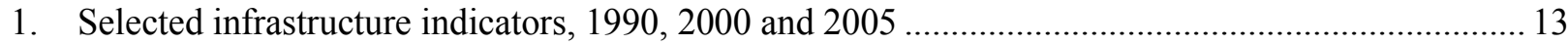

2. Indonesia: Access to infrastructure by income level, 2005 ........................................................ 15

3. Financial-sector indicators: Cross-country comparisons, 2003 .................................................. 18

A1.1. Infrastructure development and economic activity: Co-integration tests, 1970-2006 ................... 27

A2.1. The determinants of expenditure on royalties, R\&D and labour training, 1997 .......................... 29

\section{Figures}

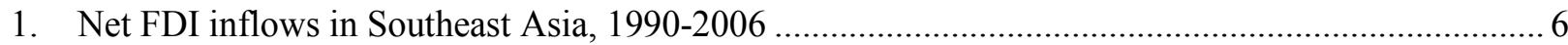

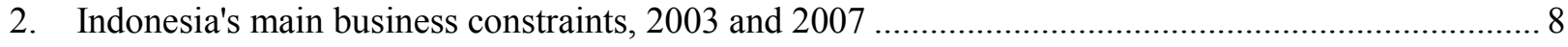

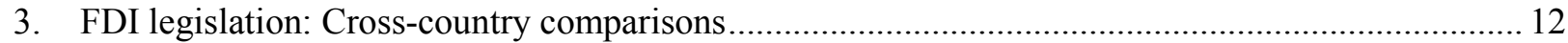

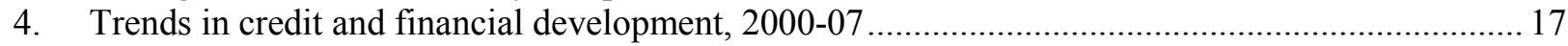


ECO/WKP(2008)46 
ECO/WKP(2008)46

\title{
Improving the business and investment climate in Indonesia
}

\author{
By \\ Diego Moccero ${ }^{1}$
}

\section{Introduction}

Indonesia needs to encourage entrepreneurship to boost potential GDP growth through the accumulation of physical capital and productivity gains. Infrastructure bottlenecks, regulatory uncertainty and poor governance are among the main obstacles to investment according to business surveys. The financial sector is by far sounder and deeper than it was ten years ago but can be developed further to allow firms easier, less costly access to alternatives sources of finance. A comfortable fiscal position is creating room in the budget for increasing public investment, especially in infrastructure development. The authorities are well aware of the need for resolute action in several policy areas and lave launched policy packages to encourage investment in infrastructure development, to promote financial development and to attract foreign investment, so as to create the necessary conditions for the private sector to play a more active role in the growth process.

This paper reviews trends in investment since the 1997-98 crisis, assesses the main impediments to entrepreneurship and discusses options for improving the business climate. Special emphasis is placed on the main provisions of the Investment Law enacted in 2007. The paper's key policy message is that the business climate needs to improve considerably to unleash opportunities for growth.

2.

Trends in investment and an assessment of the business climate

\section{Trends in investment}

Despite some renewed dynamism in fixed capital formation in recent years, Indonesia's investment-to-GDP ratio has yet to recover to its pre-crisis level and remains below those of comparator countries in the region. This has raised concern among policymakers about the country's ability to lift and maintain potential growth over the longer term and to match the growth rates of the fast-growing economies in Asia, including China and India. Of course, an economy's growth potential depends on factors other than input accumulation, including - most importantly - the efficiency with which inputs are combined to produce output. Indonesia's growth has hitherto been driven predominantly by the accumulation of inputs, suggesting that much can be done to enhance efficiency in support of faster growth, while removing remaining obstacles to capital accumulation and to effective utilisation of labour.

Foreign direct investment is an important source of finance for capital accumulation. Net FDI inflows have recovered in recent years, following a sharp reversal in the wake of the financial crisis of 1997-98.

1. The author is indebted to Mohamed Chatib Basri, Margherita Comola, Andrew Dean, Luiz de Mello, Stephen Grenville, Peter Jarrett, Hal Hill, Mohamad Ikhsan, Arianto Patunru, and the participants of the EDRC Policy Seminar on Indonesia, held on 9 June 2008, for helpful comments and discussions. Special thanks go to Anne Legendre for research assistance and to Veronique Henriksson for excellent technical preparation. 
Southeast Asia was among the most attractive FDI destinations outside the OECD area in the first half of the 1990s, a situation that changed radically following the financial crisis. Only recently have FDI inflows recovered to their pre-crisis levels in most countries (Figure 1). Indonesia was affected particularly adversely, with net FDI outflows during most of the years from 1998 to 2003. This reversal in investors' sentiment reflected a loss of confidence in the economy's growth potential following the crisis, a deterioration of the business environment with a proliferation of new business regulations by local governments after decentralisation in 2001 and more burdensome labour regulations with the enactment of a new labour code in $2003 .^{2}$

Investment - both foreign and domestic - is fairly concentrated across sectors, provinces and residency of foreign investors. While domestic investment has focused predominantly on labour-intensive sectors, such as paper, food processing, agriculture and construction, there has been considerable FDI in more capital-intensive activities, such as transport, storage and communications, and in the chemical and pharmaceutical industries. The geographical distribution of investment is also concentrated: foreign investment tends to favour locations in Java ( $80 \%$ of total FDI), whereas domestic firms also invest in Sumatra, which, together with Java, accounts for more than $80 \%$ of domestic investment. This pattern is not surprising, given that these two islands account for a large share of population and economic activity. Moreover, the top five foreign investors by country of residency (Singapore, Japan, Chinese Taipei, Korea and Australia) accounted for almost $70 \%$ of FDI in the first 10 months of 2007. ${ }^{3}$

Figure 1. Net FDI inflows in Southeast Asia, 1990-2006

In billions of current USD

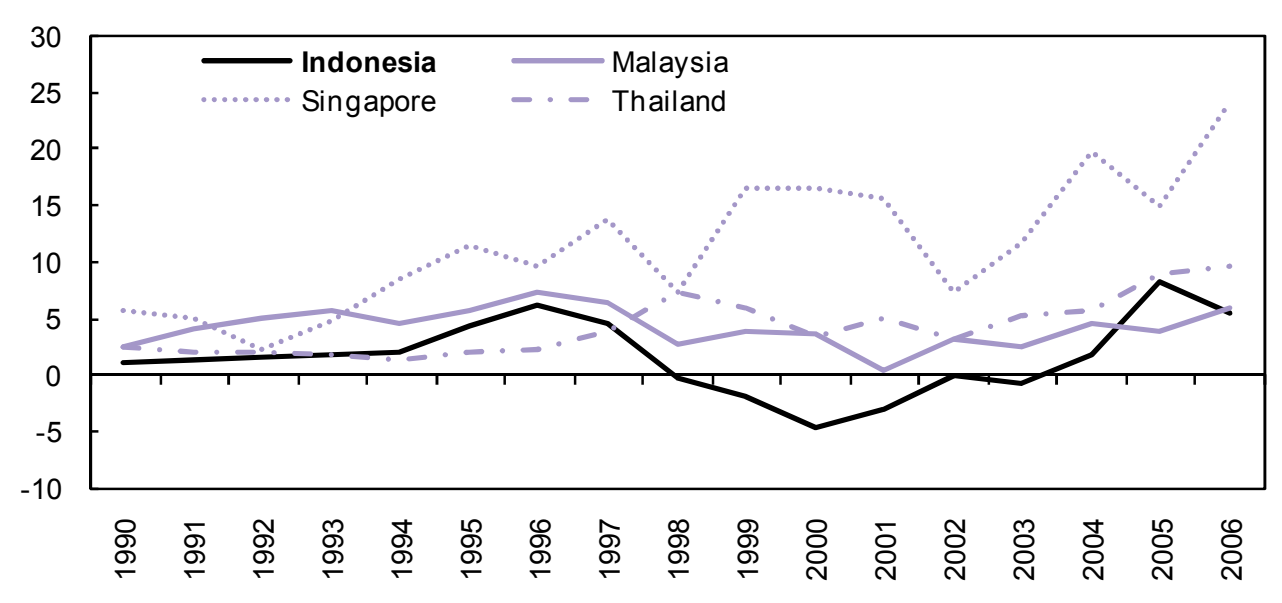

Source: UNCTAD.

\section{Indonesia's business climate}

There is considerable consensus among policymakers and the business community that a weak business environment is among the most important obstacles to investment in Indonesia. The main obstacles to entrepreneurship highlighted by the business community in surveys are: macroeconomic instability; regulatory uncertainty, including over taxes and business licensing; deficiencies in law enforcement; instability of contracts; rigidity of labour regulations and poor quality of infrastructure (Figure 2). Indonesia also fares poorly in international comparisons, despite an improvement in recent

2. See Takii and Ramstetter (2005) for more information.

3. See BKPM (2007) for more information. 
years: according to the FDI Confidence Index surveyed by A.T. Kearney, a management consulting firm, Indonesia ranked $21^{\text {st }}$ among the 25 most attractive FDI destinations in $2007 .^{4}$

Burdensome product market regulations are also detrimental to the business environment. On the basis of the OECD methodology for assessing the restrictiveness of a country's regulatory framework in product markets, Indonesia fares particularly poorly in comparison with OECD countries in policy areas related to the extent of State control in the economy, given the size and scope of the public-enterprise sector, as well as the use of command-and-control regulations. Remaining restrictions on foreign ownership of domestic firms and a proliferation of local government business regulations after 2001 (discussed below) also impinge on the business environment. These findings are consistent with alternative cross-country survey-based indicators. For example, according to the 2008 Doing Business Report published by the World Bank, Indonesia ranks $123^{\text {rd }}$ among the 178 economies that were assessed in 2007. The country fares poorly in comparison with regional peers, including Korea, Malaysia and Thailand, and in policy areas related to the ease of starting and closing a business, employing workers and enforcing contracts.

The decentralisation process that started in 2001 is perceived to have had an adverse impact on the investment climate by increasing the burden of business regulations issued by local governments. ${ }^{5}$ The devolution of some regulatory and revenue-raising functions to the districts (kota/kapubaten) has allowed them to issue business regulations, including licensing requirements, which often conflict with those set by higher levels of government. In addition, local governments have introduced a variety of non-tax levies on businesses. It is estimated that the number of such tax-related regulations rose to some 6000 between 2000 and mid-2005 (World Bank, 2006a). Whereas many of these regulations deal with changes in local tax rates or in the bases of existing taxes, others do in fact create new ones, some of which impose barriers to inter-regional trade through levies on the movement of goods. ${ }^{6}$ This is despite the fact that the central government has the prerogative to restrict the number of sectors liable for local taxation and to issue guidelines for the creation of local taxes and user charges (Law No. 34 of 2000). ${ }^{7}$ Also, according to Law No. 32 of 2004, which replaced the original decentralisation Law No. 22 of 1999, local government regulations cannot conflict with those issued by the central government.

Local governments often disguise new taxes in the form of user charges or other non-tax instruments to avoid scrutiny by the central government. It is estimated that only about $40 \%$ of the local levies created in 2000-01 were submitted for evaluation and approval by the central government, as required by law, and that only about one-half of these submissions have been effectively reviewed (World Bank, 2006a). Moreover, the proliferation of local levies creates regulatory uncertainty, because about $30 \%$ of the newly created instruments submitted for approval by the central government have been annulled. It has been

4. The Index, based on survey responses from the 1000 largest companies around the world that were responsible for $70 \%$ of FDI in 2005, focuses on the impact of political, economic and regulatory changes affecting FDI intentions. See ATKearney (2005 and 2007) for more information.

5. A survey performed in 2003 showed that around $40 \%$ of firms found that regulatory uncertainty increased after decentralisation (Asian Development Bank, 2005).

6. The fact that the salary of members of sub-national legislatures is linked to local tax collection is thought to be one of culprits for the proliferation of local taxes and levies.

7. The law is sometimes unclear. For example, it stipulates that local taxes should not run counter to the public interest and should not have a negative impact on the local economy, which is difficult to ascertain in practice. The objectives set in the law for local tax policy are the following: $i$ ) local governments should tax relatively immobile bases; $i$ ) there should be no sharing of tax bases among the different levels of government; iii) local taxes should be elastic with respect to regional income; $i v$ ) local taxes should follow principles of equity and ability to pay by local residents; and v) local taxes should safeguard the environment. 
argued that the delegation to the provinces of the authority to issue licenses for limited-liability companies has resulted in longer and costlier delays to start a business (LPEM-FEUI, 2007a). A survey conducted among notaries has shown that almost $45 \%$ of respondents find that this delegation of licensing powers has increased the cost of starting a business. This is consistent with the reported increase in the number of days required to start a business from 97 to 105 between 2006 and 2007 according to the World Bank's 2008 Doing Business Report.

Figure 2. Indonesia's main business constraints, 2003 and 2007

Per cent of firms reporting the issue as a business constraint ${ }^{1}$

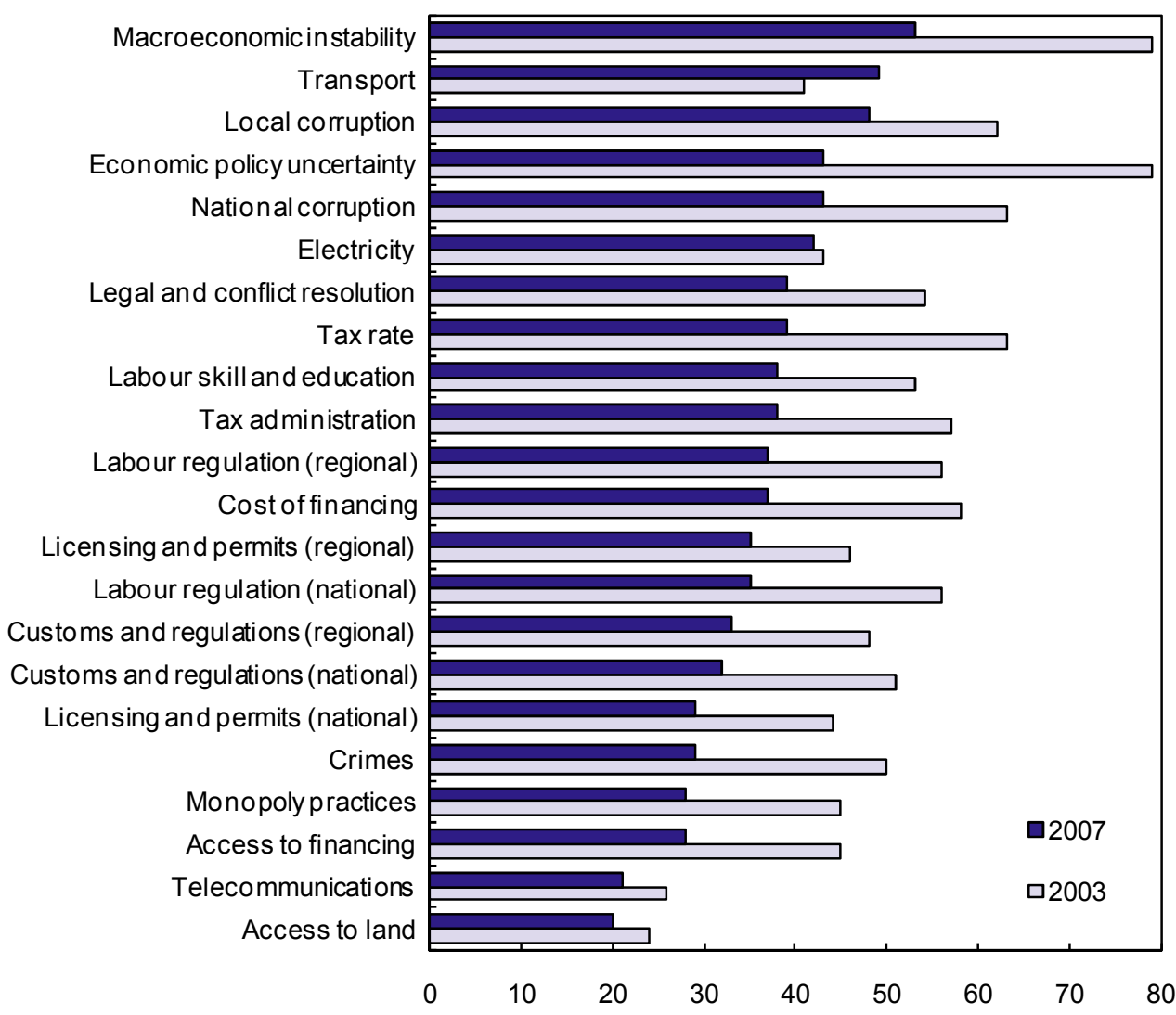

1. Data for 2003 is available from Asian Development Bank (2003) and for 2007 from LPEM-FEUI (2007a).

Source: Asian Development Bank (2003) and LPEM-FEUI (2007a).

To the extent that it has increased the number of officials with discretionary power over economic activity, and because it has made regulations more complex, decentralisation is likely to have increased opportunities for corruption. ${ }^{8}$ Surveys conducted at the firm level show that bribes and informal payments increase the effective tax burden on the business sector by about $50 \%$ and that these payments rise in proportion to the number of business licenses required by local governments. Corruption also creates

8. The association between fiscal decentralisation and corruption is complex and depends, among other things, on how sub-national spending is financed. See de Mello and Barenstein (2001) for a review of the literature and empirical evidence for a cross-section of countries. Also, Bardhan (1997) shows that under "decentralised corruption", bribery may be more widespread than in "centralised corruption". 
barriers to domestic trade, because illegal road charges increase transport costs. The most common bribes are for speeding up the issuance of business permits and licenses, for securing contracts and concessions, and for obtaining and renewing the necessary work/immigration permits for expatriates. Incidentally, a survey conducted among manufacturing firms showed that, by mid-2007, almost $90 \%$ of responding firms had occasionally or frequently paid a bribe to government officials (LPEM-FEUI, 2007a). Overall, decentralisation is supposed to have increased business uncertainty, which makes the investment climate less predictable.

Indonesia fares rather poorly in international surveys of good governance. The country lagged behind regional peers, such as the Philippines, Thailand and Malaysia, and particularly Singapore, according to the Transparency International indicators of perceived corruption in 2007. This is in spite of progress over the recent past, since investment-climate surveys carried out in Indonesia show a decline in the share of firms stating that national and local corruption poses an obstacle to entrepreneurship (Figure 1). Nevertheless, it appears that the impact on business perceptions of efforts to fight corruption may be tapering off: the percentage of survey respondents who think that corruption will decrease in the near future has declined. The surveys conducted by Transparency International show that, in 2005, almost $80 \%$ of respondents thought that corruption was going to decrease in the following three years, but that share fell to $22 \%$ in 2007. Of course, the evidence provided in opinion surveys needs to be interpreted with caution: it is difficult to measure corruption accurately, given that most evidence available to date refers to perception indicators, which may not always reflect progress in efforts to improve governance.

\section{Recent policy initiatives to improve the business environment}

The authorities are aware of the need to take decisive action in several policy areas to improve the business environment in support of faster growth. An important recent initiative was a strengthening of the country's FDI regime with the enactment of a new Investment Law in 2007 (Box 1). The new legislation simplifies regulations, protects property rights and provides tax incentives for investment (Narjoko and Jotzo, 2007). In particular, it ensures, among other things, equal treatment for domestic and foreign investors. Also, equity restrictions on foreign ownership and several sectoral barriers to foreign participation have been relaxed, at least in part, in telecommunications; air transportation and port management; power generation, transmission and distribution; shipping; water supply; and nuclear power generation. Restrictions remain in a few sectors that are considered sensitive to national interests, such as religion, culture, the environment, and small and medium-sized enterprises (SMEs). Moreover, the issuance of a "negative list" to unify existing sectoral restrictions on foreign involvement has rendered regulations more transparent to foreign investors. By and large, there is a general perception among investors that the new law improves considerably upon the previous legislation. Nevertheless, implementing regulations for several provisions of the law are yet to be issued.

Efforts have been made to promote investment opportunities. The authorities have the intention of converting the Investment Co-ordinating Board, created in 1973 essentially as a screening and authorising agency for foreign investment, into a fully-fledged investment promotion agency. ${ }^{9}$ They also aim to strengthen the Board to improve co-ordination among the various government agencies involved in investment regulations. They are working towards reducing the number of procedures needed for approval of new investments and intend to cut back the approval period to one month from the current 105 days.

9. The Investment Co-ordinating Board is in charge of designing investment policy, including by identifying potential investment opportunities; issuing norms, regulations, standards and procedures; promoting partnerships between the business and academic communities; disseminating information to boost competition; and fostering co-ordination among the different levels of government, regulatory agencies and the central bank. 
Initiatives are under way at the local government level to facilitate the issuance of business licenses. Several local governments are setting up business licensing centres as a means of dealing with the uncertainty associated with the proliferation of local business regulations. As in other decentralised countries, the licensing process involves many procedures at different government levels. Verification of compliance with zoning rules and health and safety standards, as well as the issuance of tax registration documentation and product- or activity-specific licenses, require involvement not only of the national and local governments, but also of local business associations. One-stop shops (OSSs) have been set up to consolidate the processing of business licenses issued by separate bodies. The Minister of Home Affairs has recently issued general guidelines on how to establish these regional OSSs. ${ }^{10}$

\section{Box 1. The 2007 Investment Law}

Law No. 25 of 2007 and related regulations unify Indonesia's legal framework for foreign investment. The law improves upon the 1967 foreign investment law and the 1968 domestic investment law. Its main provisions are the following:

Domestic and foreign investors. The Law ensures equal legal status and treatment of domestic and foreign investors. Until then, separate pieces of legislation had regulated national and foreign investment. The Law also scrapped the divestiture provisions that existed for foreign investors in previous legislation (the 1967 Foreign Investment Law).

Investor protection. The Law protects investors against expropriation by stating that owners should be compensated at the market value of assets, should they be seized or nationalised. It also guarantees foreigners the right to make international currency transfers to repatriate earnings, dividends and profits; to purchase inputs or productive capital; to reimburse loans; and to contract for foreign technical assistance.

Dispute resolution. Disputes between the government and foreign investors may be settled by international arbitration.

Negative list. Foreign investment is allowed in all sectors/activities, except for those explicitly listed by the Law. Protected sectors/activities may be "closed" or "open with restrictions". They are closed when they are considered strategic or reserved for small and medium-sized enterprises (SMEs), and open with restrictions when joint-venture provisions, location conditions, ownership caps and special licensing requirements apply.

Land property rights. The Law strengthens property rights by extending the period during which land can be leased. The maximum holding of land for cultivation, building rights and land use is extended from 35,30 , and 25 to 95,80 , and 75 years, respectively.

Immigration procedures. The Law allows greater mobility of foreign professionals. Expatriates may be granted two-year residency permits and multiple-entry visas. After two years of continuous residency, the work permit may be converted into a permanent residency permit.

Tax incentives. The Law provides tax breaks for projects that create employment, promote infrastructure and technological development, and develop rural areas and pioneer industries. Special tax incentives include tax holidays for infant industries and/or innovative enterprises, income tax reductions, exemption or reduction of import duties and value added tax on purchases of capital goods and raw materials, accelerated depreciation for investment, and property tax relief.

Commitment to a reduction of red tape. The Law stipulates the establishment of one-stop-shop (OSS) services for investment applications, and centralises the registration process at the national level, a task assigned to the Investment Co-ordinating Board (BKPM).

10. International organisations, such as the Asia Foundation and the German Technical Co-operation (GTZ), have also been working with local jurisdictions to improve the performance of OSSs in areas related to management capacity, licensing practices and the application of information and communication technology to business registration. 
The government intends to provide tax incentives for investment, as stated in the Investment Law. The broad contours of these incentives have already been defined, although the amounts involved and the actual modalities have yet to be set. They would target investors in priority areas, such as remote regions and special economic zones, priority business activities (e.g. infrastructure and R\&D), and labour-intensive sectors involving partnerships with SMEs. The main incentive instruments would include income-tax breaks, reductions in import duties on inputs and raw materials, and the introduction of value-added tax holidays for imported capital machinery and equipment not produced locally, as well as reductions in land and building-related taxes.

Anti-corruption efforts are being stepped up. An anti-corruption law was enacted in 1999, following the financial crisis and the change in government (Box 2). The government launched a high-profile anti-corruption campaign in 2004 in recognition of the need to take steadfast action to improve governance. More recently, efforts to curb corruption in the public sector have focused on increasing civil servants' compensation and budgetary appropriations for several agencies involved in internal and external control. All in all, anti-corruption efforts seem to be paying off, at least as gauged by a reduction over time in the share of survey respondents stating that national and local corruption is a problem for business development (Figure 2). Moreover, the number of corruption investigations and prosecutions increased significantly between 2004 and 2005, including at all levels of governments and State-owned enterprises (World Bank, 2006a).

\section{Box 2. An overview of anti-corruption initiatives}

Anti-corruption legislation was passed in 1999, including the creation of a Commission for Eradication of Corruption (KPTPK). The law was amended in 2001 to deal with issues not covered in the original legislation, including rules on gratuities received by public employees.

Additional measures were taken in 2004. The institutional framework for fighting corruption was strengthened, including through greater autonomy granted to newly created institutions, such as the KPTPK and the Anti-Corruption Court. Existing institutions, such as the Supreme Audit Commission, the Financial Transactions and Analysis Centre (PPTAK) and the Attorney General's Office, were encouraged to become more active in combating corruption. To prevent illicit personal enrichment, high-ranking officials are now required to fill in a personal wealth report, which is an important step in the area of corruption prevention.

Recent initiatives to fight corruption include an increase in budgetary appropriations from 2008 to finance an increase in civil servants' compensation by $20 \%$, the introduction of payment of a $13^{\text {th }}$ monthly salary to civil servants and an increase in the value of food allowances received by civil servants. Budget allocations have also been raised significantly for almost all institutions involved in strengthening governance and law enforcement (Supreme Audit Agency, Supreme Court, Ministry of Law and Human Rights and the Attorney General's Office).

\section{Indonesia's FDI regime: International comparisons}

Despite the recent efforts to liberalise Indonesia's FDI regime, remaining restrictions are relatively burdensome by international comparisons. On the basis of the OECD methodology for assessing the stringency of regulations on FDI, described in Box 3, Indonesia's overall score is stricter than those of most countries in the OECD area, except Australia, Iceland and Mexico (Figure 3). This implies that those latter three countries impose more restrictions on foreign investment than Indonesia. Nevertheless, Indonesia fares better than the BRICS group of countries, except Brazil and South Africa, suggesting that it is relatively well placed in relation to other major emerging-market economies, which are among the most attractive destinations for FDI outside the OECD area. 
Figure 3. FDI legislation: Cross-country comparisons ${ }^{1}$

Low scores indicate less restriction

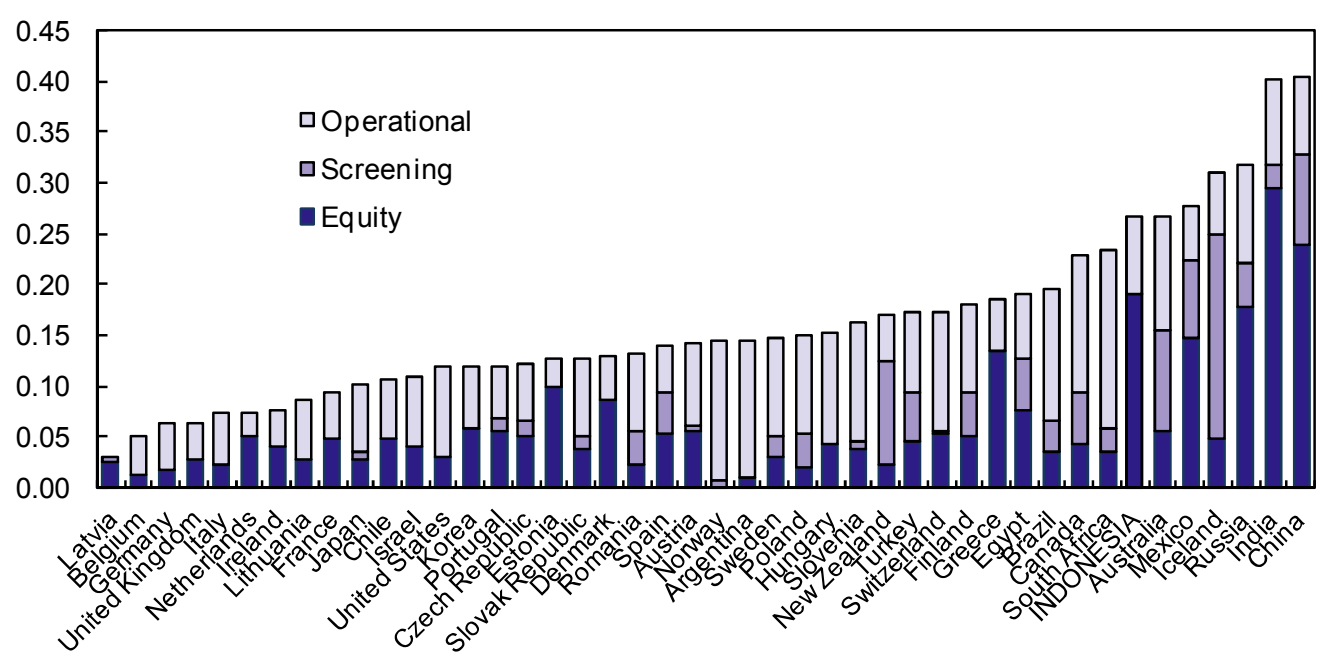

1. Refers to the state of legislation in 2007 for Indonesia and in 2006 for all other countries.

Source: OECD (2006) and OECD calculations.

On the basis of the OECD indicator, Indonesia's FDI regime is particularly stringent on foreign ownership. Caps on equity holdings are especially restrictive in the transport sector, including air, maritime and surface transport, and in telecoms, mainly with respect to the provision of fixed-line services. With respect to operational and screening requirements, they are less restrictive than in most OECD countries, although bureaucratic hurdles remain on international labour mobility. Although there is no formal restriction on the nationality of Board members, managers and workers in general, the 2007 Investment Law states that priority should be given to Indonesian citizens. Also, although foreign workers are allowed to obtain an initial two-year work permit, this is subject to approval by the General Directorate for Migration, based on a request by the Investment Co-ordinating Board.

\section{Box 3. The OECD methodology for calculating FDI regulatory restrictiveness}

The restrictiveness of a country's FDI regulations has been calculated for OECD and selected non-OECD countries using a methodology presented in OECD (2006). The scoring methodology intends to measure deviations from national treatment against foreign investment. For example, regulations of labour and product markets that apply equally to both foreign and domestic investors are not considered when calculating the restrictiveness indicators. Only statutory barriers are accounted for; tacit institutional, informal or behavioural restrictions to FDI are therefore excluded.

Restrictiveness is measured on a 0-1 scale, with 0 representing full openness and 1 an outright prohibition of FDI. Three main restrictions are considered: $i$ ) limitations on foreign equity holdings; ii) screening and notification requirements; and iii) other restrictions, such as those on management, operations and movement of expatriate workers. Equity restrictions receive the highest weight in the indicator. If foreign equity if banned, the other criteria become irrelevant, and the score reaches its maximum value.

FDI restrictions can apply across the board or only to specific sectors. For each country, the index covers 9 sectors and 11 sub-sectors (in parentheses): i) professional services (legal, accounting, engineering and architectural), ii) telecommunications (fixed and mobile), iii) transport (air, maritime and road), iv) finance (banking and insurance), v) retailing, vi) construction, vii) hotels and restaurants, viii) electricity and ix) manufacturing. Because investment in energy, including oil and gas, varies substantially across countries depending on their natural endowments, energy other than electricity is not covered by the methodology. Restrictiveness is scored at the sectoral level, and a national average is computed using trade and FDI weights. 


\section{Dealing with infrastructure bottlenecks}

\section{Trends in spending and performance}

The development of basic infrastructure was among the authorities' priorities in the 1970s and 1980s. Projects were financed and carried out by the government in areas related to transport, electricity and telecommunications. Total investment in infrastructure building accounted for around 10\% of GDP at the time. By 2007 this ratio had fallen substantially, despite a strong recovery since 2000. Government spending on infrastructure development has now recovered, although it still remains below to its pre-crisis level. But private investment has yet to bounce back, a trend that can be explained at least in part by concern over the legal and regulatory environment.

Indonesia has some of the poorest infrastructure development indicators in Southeast Asia (Table 1). According to the 2002-03 Global Competitiveness Report, the overall quality of Indonesia's infrastructure was ranked $64^{\text {th }}$ out of the 80 countries surveyed. Moreover, based on national opinion surveys, bottlenecks in energy and transport are the most pressing infrastructure-related obstacles to business development (Figure 1). A survey carried out by the World Bank on eleven countries in Asia and Australia placed Indonesia in seventh position regarding clean water supply (World Bank, 2004).

Table 1. Selected infrastructure indicators, 1990, 2000 and 2005

\begin{tabular}{|c|c|c|c|c|c|}
\hline & \multicolumn{3}{|c|}{ Indonesia } & \multirow{2}{*}{$\begin{array}{l}\text { Southeast } \\
\text { Asia }\end{array}$} & \multirow{2}{*}{ OECD } \\
\hline & 1990 & 2000 & 2005 & & \\
\hline \multicolumn{6}{|l|}{ Water/Santitation } \\
\hline $\begin{array}{l}\text { Improved sanitation facilities (per cent of } \\
\text { population with access) }\end{array}$ & 46 & 52 & $55^{1}$ & $50.6^{1}$ & $100^{1}$ \\
\hline $\begin{array}{l}\text { Improved water source (per cent of population } \\
\text { with access) }\end{array}$ & 72 & 76 & $77^{1}$ & $78.5^{1}$ & $99.5^{1}$ \\
\hline \multicolumn{6}{|l|}{ Energy and transport } \\
\hline $\begin{array}{l}\text { Electric power consumption (kWh per capita) } \\
\text { Electric power transmission and distribution } \\
\text { losses }\end{array}$ & 161.4 & 400.4 & $478.2^{1}$ & $1343.5^{1}$ & $9693.5^{1}$ \\
\hline (per cent of output) & 13.7 & 10.9 & $13.4^{1}$ & $7.0^{1}$ & $6.2^{1}$ \\
\hline $\begin{array}{l}\text { Electricity production composition by source (in } \\
\text { per cent) }\end{array}$ & & & & & \\
\hline Coal & 31.5 & 36.7 & $40.1^{1}$ & $69.1^{1}$ & $37.9^{1}$ \\
\hline Natural gas & 2.3 & 28.2 & $16.1^{1}$ & 2.3 & 28.2 \\
\hline Oil & 42.7 & 19.1 & $30.2^{1}$ & 41.1 & $4.3^{1}$ \\
\hline Other & 23.5 & 16.1 & $13.6^{1}$ & 56.7 & 71.8 \\
\hline Roads, paved (per cent of total roads) & 45.1 & 57.1 & .. &.. & $100^{1}$ \\
\hline \multicolumn{6}{|l|}{ Information and communication technologies } \\
\hline (per 1000 people) & 6.1 & 50.1 & 270.6 & 496.5 & $1324.5^{1}$ \\
\hline International Internet bandwidth (bits per person) & & 1.2 & $6.9^{1}$ & 97.1 & $4731.5^{1}$ \\
\hline Internet users (per 1000 people) & 0.0 & 9.2 & 72.5 & 88.7 & 525.4 \\
\hline Personal computers (per 1000 people) & 1.1 & 10.2 & $13.9^{1}$ & $38.2^{1}$ & $585.2^{1}$ \\
\hline
\end{tabular}

1. Refers to 2004.

Source: World Bank (World Development Indicators).

In electricity, access is low even by regional standards, in spite of substantial improvements over recent decades. Efficiency is also poor, as gauged by energy losses in distribution. The likelihood of energy shortages has increased substantially in recent years, given that demand growth has outpaced the expansion 
of supply. Power outages are particularly detrimental to enterprises in electricity-intensive sectors, such aselectronics, chemicals and textiles, because firms must pay for their own generators to secure a steady flow of electricity. Connection to the electricity grid also poses an economic burden on firms, because they have to pay upfront for the installation of meters and related equipment. ${ }^{11}$ Production costs have also risen substantially over the recent past, because around $30 \%$ of electricity generation is oil-based. Notwithstanding these problems, opinion surveys suggest that business perceptions of the quality and quantity of infrastructure have improved in gas, electricity, water/sanitation and physical road conditions between 2006 and 2007 (LPEM-FEUI, 2007a).

Transportation infrastructure is also poor. Urban roads are severely congested, and several important toll-road projects, such as Jakarta's outer ring-road and the trans-Java highway, have yet to come to fruition. It is estimated that $43 \%$ of the road network in Java is congested, a figure that is expected to rise to $55 \%$ by 2010 , if demand growth continues to outpace that of supply (World Bank, 2007). The quality of national and provincial roads is nevertheless considered to be in line with regional comparators. But district roads tend to lack essential maintenance, and some of the poorest areas of the country, especially the Eastern islands, still lack all-season roads. The costs of owning a motor vehicle are found to be higher in Indonesia than in other Asian countries, due in part to damaged roads (LPEM-FEUI, 2007b). Given Indonesia's geography, port infrastructure is essential for the economic integration of distant regions and for facilitating international trade. ${ }^{12}$ Overall, poor infrastructure reduces the competitiveness of the manufacturing sector, because it raises operating costs and increases travel time between plants and consumer markets. Logistical costs, including transportation and related charges, may reach as much as $14 \%$ of total production costs in Indonesia, against about 5\% in the case of Japan (LPEM-FEUI, 2005).

Improvements in water/sanitation infrastructure can yield dividends in terms of poverty alleviation, because poor people tend to have less access to services (Table 2). Poor health and the prevalence of water-borne diseases affect the earnings capabilities of vulnerable individuals, who need to take time off work due to illness. At around 30\% on average, access to piped water in urban areas is among the lowest in the region, well behind countries such as Malaysia, Philippines, Thailand and Vietnam. Access to waste-water treatment is even lower: it is estimated that only about $1.3 \%$ of the population of Jakarta is connected to a sewerage system. The remainder of the population relies on septic tanks, from which untreated sewage often leaks into the ground, polluting water sources and facilitating the spread of communicable diseases. Access to water supply also imposes a financial burden on enterprises, because the PDAMs, the State-owned water companies, use a cost-sharing scheme according to which firms need to bear upfront the full cost of connectivity. As in the case of transport, there are important differences in the quality of infrastructure across the country, with the Eastern provinces typically lagging behind Java-Bali and Sumatra.

To some extent, capacity constraints at the local government level have taken a toll on infrastructure development. Because of skills shortages and limited operational capabilities, local governments have often been unable to take on the spending assignments devolved to them by the central government in the course of decentralisation. This is despite the fact that most investment spending continues to be financed by the centre through intergovernmental transfers according to Indonesia's revenue-sharing system. Capacity shortages are thought to be most severe in areas related to project design and development, resulting in implementation delays. A lack of clarity about the spending functions of each government level is another culprit. Moreover, as in other decentralised countries, local governments sometimes do not

11. In particular, firms are required to buy their own transformers in a cost-sharing scheme: they pay lower electricity fees for some agreed period of time, after which ownership of the transformer is transferred to PLN and the firms start paying the normal fee.

12. Poor port infrastructure has contributed quite significantly to an increase in average waiting time for loading and unloading activities in ports (Patunru et al., 2007). 
have incentives to invest in infrastructure, especially when projects create externalities for neighbouring jurisdictions. Finally, the government's anti-corruption efforts, while laudable, are believed to have slowed infrastructure building. This may be an ineluctable short-term cost associated with efforts to enhanced accountability at the local level of government over time. Anecdotal evidence suggests that local officials often fear being charged with misconduct when committing budgetary resources to large investment projects.

Table 2. Indonesia: Access to infrastructure by income level, 2005

\begin{tabular}{|c|c|c|c|c|c|}
\hline \multicolumn{6}{|c|}{ In per cent of households } \\
\hline & $\begin{array}{l}\text { Lowest } \\
\text { quintile }\end{array}$ & Quintile 2 & Quintile 3 & Quintile 4 & $\begin{array}{l}\text { Highest } \\
\text { quintile }\end{array}$ \\
\hline \multicolumn{6}{|l|}{ Sources of drinking water } \\
\hline Piped water & 9.3 & 12.5 & 16.9 & 23.8 & 37.4 \\
\hline Pump & 6.5 & 7.7 & 9.2 & 10.7 & 12.8 \\
\hline Well & 50.8 & 50.1 & 47.8 & 43.2 & 31.1 \\
\hline Spring & 22.6 & 16.8 & 12.8 & 9.0 & 4.4 \\
\hline Other & 10.7 & 12.9 & 13.3 & 13.3 & 14.4 \\
\hline \multicolumn{6}{|l|}{ Waste water disposal $^{1}$} \\
\hline Septic tank & 10.0 & 15.4 & 23.7 & 36.6 & 62.0 \\
\hline Untreated disposal in water & & & & & \\
\hline bodies (rivers, lakes and ocean) & 25.1 & 25.3 & 23.8 & 21.0 & 12.9 \\
\hline Hole & 31.1 & 30.8 & 28.0 & 23.2 & 14.9 \\
\hline Other & 33.7 & 28.6 & 24.5 & 19.2 & 10.2 \\
\hline \multicolumn{6}{|l|}{ Toilet facilities } \\
\hline Private & 40.4 & 48.6 & 56.0 & 67.4 & 82.5 \\
\hline Shared & 14.7 & 13.7 & 13.4 & 12.1 & 9.0 \\
\hline Other & 44.9 & 37.8 & 30.6 & 20.6 & 8.5 \\
\hline \multicolumn{6}{|l|}{ Sources of light ${ }^{1}$} \\
\hline Electricity supplied by PLN & 39.8 & 50.1 & 60.1 & 72.1 & 87.6 \\
\hline Torch & 45.9 & 36.1 & 26.4 & 15.9 & 4.9 \\
\hline Other & 14.3 & 13.8 & 13.5 & 12.0 & 7.6 \\
\hline \multicolumn{6}{|l|}{ Access to ICT } \\
\hline Fixed line & 1.1 & 2.5 & 4.5 & 11.4 & 38.1 \\
\hline Mobile phone & 1.0 & 3.9 & 9.0 & 21.3 & 55.5 \\
\hline Internet connection & 0.1 & 0.2 & 0.5 & 1.3 & 8.9 \\
\hline
\end{tabular}

1. Refers to 1996.

Source: Susenas and OECD calculations.

Investment in the mining and forestry sectors is also surprisingly low. This is in spite of high commodity prices in recent years and ample potential for development, given Indonesia's abundant natural resources. Before 1998, Indonesia attracted over 5\% of the world's mining exploration investment, as opposed to just $0.5 \%$ over the recent past. This fall in attractiveness can be attributed to the business climate more generally, including weaknesses in the regulatory framework. High taxes and governance problems, including deficiencies in the enforcement of contracts, have also discouraged investment.

\section{Empirical evidence and recent policy initiatives}

There is considerable potential for boosting potential growth by removing existing infrastructure bottlenecks. The link between infrastructure and growth tends to be stronger in lower-income countries, 
such as Indonesia, where infrastructure deficiencies are most pressing than in more developed countries in the OECD area. But the actual magnitude of the effect of infrastructure development on growth can only be gauged empirically. To shed some light on this issue, the empirical evidence reported in Annex A1 suggests that a $1 \%$ improvement in a composite infrastructure indicator is associated with an increase in GDP of nearly $0.9 \%$ in the long run. The analysis is based on physical measures of infrastructure in energy, transport and information and communication technology (ICT), instead of estimates of capital stock computed from investment flows. This approach avoids the need to quantify the capital stock, which is not without pitfalls, especially in an environment of volatile inflation, and the difficulties of assessing the efficiency with which private and public inputs are combined to produce infrastructure outputs. Estimation of a strong association between infrastructure development and growth is consistent with previous analysis for Indonesia. For example, simulations conducted by LPEM-FEUI show that increasing electricity generation capacity alone by $5 \%$ would boost economic growth by about 0.3 percentage points.

Efforts are under way to encourage private-sector involvement in infrastructure development (Box 4). A number of high-profile infrastructure summits have taken place since 2005 to bring together domestic and foreign investors, as well as government officials. These summits have sought to disseminate information on investment opportunities in areas such as transport, electricity, telecommunications, oil and gas, and water/sanitation. The authorities' strategy is to focus on non-economically viable projects, while encouraging the private sector to explore commercially viable investment opportunities. Efforts to improve the regulatory framework in network industries have yielded mixed results. The government enacted a new electricity law in 2002 introducing open competition for power generation from 2007 and abolishing the State-owned company's (PLN) monopoly in distribution by allowing entry of both foreign and domestic private companies. Unfortunately, the law was overturned by the Constitutional Court in 2004. The government is currently drafting a new electricity law but has not yet submitted it to Parliament.

\section{Box 4. Efforts to encourage private-sector involvement in infrastructure development}

The government launched an Investment Policy Package in 2006 with the aim of boosting institutional capacity and co-ordination among the line ministries dealing with infrastructure development and regulation, such as the ministries of Finance, Energy and Mineral Resources, and Public Works. The Package deals with changes in laws and regulations, and sets policy objectives for fostering competition, eliminating barriers to private participation in infrastructure and improving the regulatory framework. Government support for infrastructure is also evidenced in the 2008 Budget Law, which raised budgetary appropriations for the ministries in charge of infrastructure, especially the ministries of Public Works, Communications, and Energy and Mineral Resources.

As a way of boosting public-private partnerships, the National Committee on Policy for Accelerating Infrastructure Provision (KKPPI) was established in 2005 as an inter-ministerial body. Within the KKPPI, a Public-Private Participation (PPP) Unit was set up as a centre of technical expertise in project preparation, using as a benchmark international best-practice guidelines. In turn, a Risk Management Unit (RMU) was established at the Ministry of Finance to evaluate the projects prepared by the PPP Unit and to deliberate on the allocation of government financial support for private investors. This is with the aim of ensuring appropriate risk sharing between the public and private sectors and dealing with private-sector concerns about the long-term financial viability of projects.

The authorities also agreed to provide credit support for selected infrastructure projects, including a PLN-owned power plant and the Trans-Java toll-road project. In 2006, the government also approved new implementing regulations related to roads, railways, shipping, aviation and utilities. Furthermore, it has promoted the establishment of self-regulatory bodies for the toll roads, oil and gas, telecommunications and water supply. As for land acquisition, which has been the main impediment for toll-road projects, the government has established a new working team to overcome land acquisition problems, and has allocated 600 billion rupiah to the infrastructure fund managed by the Government Investment Unit.

\section{Enterprise access to credit}

A shallow financial market makes it difficult for firms, especially SMEs and those operating in the informal sector, to obtain credit at competitive rates. The stock of outstanding credit has risen over the 
years on the back of an increase in consumption loans until 2006 (Figure 4), although credit for investment and working capital recovered somewhat in 2007. Also, at around $21 \%$ of GDP in 2007, the credit ratio is lower than in regional comparator countries, such as Malaysia, Thailand and Korea, where credit accounts for more than $100 \%$ of GDP. Non-bank credit to enterprises, especially through fixed-income and equity markets, is also limited in Indonesia.

The Indonesian financial sector is comparatively small in relation to regional peers. Banks account for the lion's share of financial institutions' assets, and State-owned banks make up around 35\% of bank assets (Table 3). Another consideration is that there are limited sources of long-term finance in the banking sector, since nearly all deposits have short maturities (three months or less). The banking sector is also concentrated, with major banks accounting for almost $70 \%$ of bank assets. The non-bank segment, which is dominated by pension funds, is developing fast but still has ample scope for further expansion.

Figure 4. Trends in credit and financial development, 2000-07

A. Trends in investment and consumption credit ${ }^{1}$

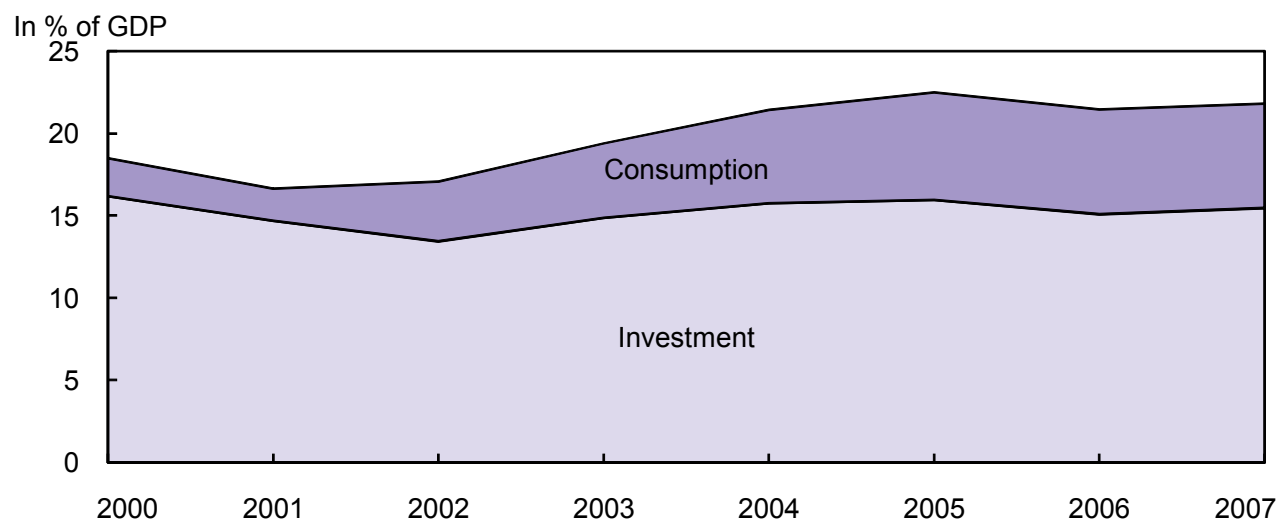

B. Equity and corporate bond markets ${ }^{2}$

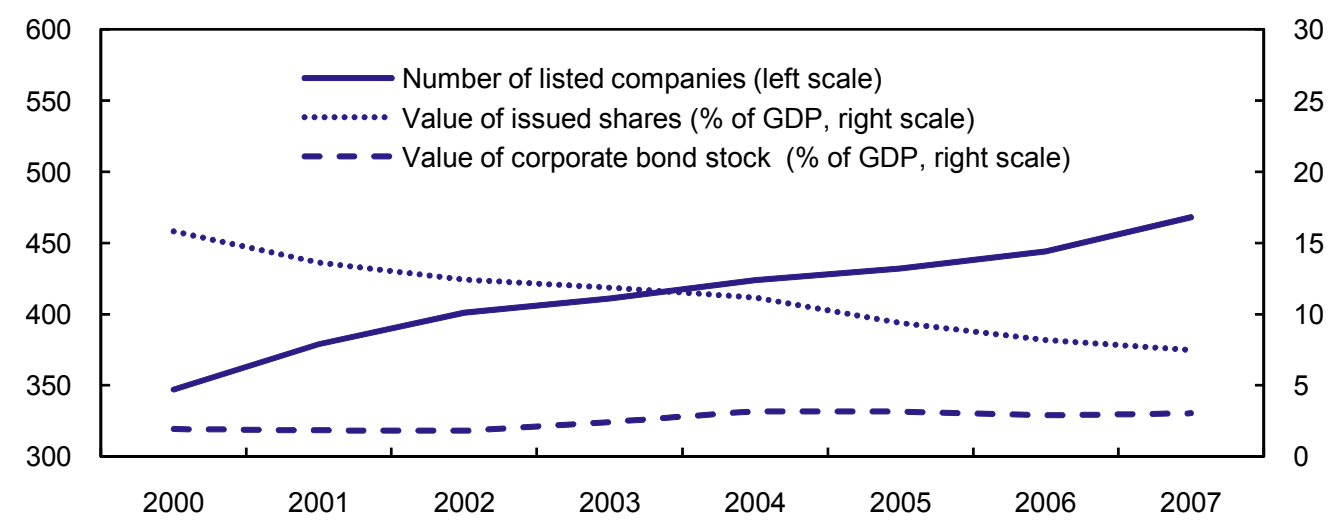

1. Investment credit includes loans for working capital. Consumption credit includes housing and motor vehicle loans, credit cards and others.

2. The number of listed companies refers to December for all years.

Source: Bank Indonesia.

Access to credit is particularly difficult for SMEs, especially those operating in the informal sector. This is the case in most countries, not only in Indonesia. Banks are often unable, and unwilling, to lend to borrowers with limited recoverable collateral. For example, despite considerable improvements in some 
regions, land-property rights are poorly defined, which constrains the ability of small borrowers to use their own property as collateral when applying for loans. When banks do lend, terms and conditions are typically harsher than in the case of larger enterprises or those formally registered. This problem is aggravated by a weak judicial system because of lengthy and costly loan-recovery procedures. Unequal access and terms of credit impose a constraint on the ability of SMEs to break out of a vicious circle of low growth and informality in which they are often trapped. To some extent, these shortcomings may be compensated, at least in part, by information on firms' credit history, which can be used to gauge creditworthiness. But if such information is not easily available to different financial institutions, enterprises become captives of the banks from which they borrow. This reduces the scope for competition among banks, which could facilitate access to, and reduce the cost of, credit. ${ }^{13}$

Table 3. Financial-sector indicators: Cross-country comparisons, 2003

In per cent of GDP

\begin{tabular}{lcrrr}
\hline \multicolumn{1}{c}{ Sector } & Indonesia $^{1}$ & Malaysia & Thailand & Singapore \\
\hline Bank and non-bank assets & & & & \\
Banks & $\mathbf{6 8 . 1}$ & 293.8 & 147.6 & 401.3 \\
Non-banks & $\mathbf{5 3 . 9}$ & 159.8 & 114.9 & 233.4 \\
Insurance companies & $\mathbf{1 4 . 2}$ & 134.0 & 32.7 & 167.9 \\
Pension funds & $\mathbf{2 . 8}$ & 19.5 & 3.4 & 49.8 \\
Mutual funds & $\mathbf{4 . 3}$ & 56.4 & 4.8 & 65.7 \\
Outstanding corporate bonds & $\mathbf{1 . 1}$ & 20.1 & 12.2 & 20.0 \\
Others & $\mathbf{2 . 3}$ & $38.0^{2}$ & $12.3^{2}$ & $32.4^{2}$ \\
Stock market capitalisation & $\mathbf{3 . 7}$ & 0.0 & 0.0 & 0.0 \\
\hline
\end{tabular}

1. Refers to 2005.

2. Refers to 2004.

Source: World Bank (2006b).

The strengthening of the banking sector after the 1997-98 crisis has fulfilled an important framework condition for the expansion of credit and the development of the non-bank market segment. Conventional indicators, such as the share of non-performing loans in loan portfolios, capital-adequacy ratios and profitability indices, have improved markedly over the years. Whereas before the crisis the banking sector was predominantly privately owned, the government's share in the sector's assets rose considerably thereafter as a result of the need to rescue failing institutions in the wake of the crisis. Recent policy efforts have focused on the upgrading of financial safety nets and the adoption of international banking standards. A limited deposit insurance mechanism has now replaced the blanket guarantee scheme that was put in place at the time of the crisis. A deposit insurance agency has also been created, and Basel II standards will be adopted, starting in 2008 and becoming fully operational by $2010 .{ }^{14}$

The monetary authorities believe that further consolidation in the banking sector would allow banks to reap the benefits of economies of scale. This would result in efficiency gains and lower intermediation

13. Recognising the need to take action in this area, Bank Indonesia launched a Debtor Information System (DSI) in 2005. DSI initially covered borrowers with loans above 50 million rupiah, which excluded small enterprises, but was subsequently extended to all loans.

14. The new deposit insurance scheme is funded by a bi-annual payment of $0.1 \%$ of bank deposits and government resources. The deposit insurance agency is responsible for the resolution and management of failed banks. A co-ordinating committee including representatives of Bank Indonesia, the Ministry of Finance and the deposit insurance agency decides if a failed bank is of systemic importance or deserves liquidation. 
costs. Consolidation could also facilitate banking supervision by allowing Bank Indonesia to focus on fewer, larger institutions. To this end, a series of measures have been taken by Bank Indonesia to encourage mergers in the banking system. These include a single-bank-ownership policy (i.e. institutional investors can have a majority stake in only one commercial bank), the introduction of tax breaks to encourage bank mergers and a gradual increase in minimum core-capital requirements (from 80 billion rupiah in 2007 to 100 billion rupiah in 2010).

Measures have also been taken to boost credit. Recent initiatives include a loosening of some prudential regulations: capital requirements have been relaxed through lower risk weights, including for corporate bond holdings, and provisioning and loan classification procedures have been eased for sub-prime borrowers, especially for small enterprises and borrowers that have defaulted on previous credits. Bank Indonesia has introduced a scheme of rising reserve requirements to penalise banks with lower loan-to-deposits ratios. A Banking Policy Package was announced by the central bank in March 2008 to facilitate access to the banking sector by small enterprises. Moreover, State-owned banks have been encouraged to be more active in financing infrastructure projects and in maintaining higher credit growth rates. Finally, registration and licensing procedures have been simplified for banks. The authorities believe that these measures are consistent with concomitant efforts to strengthen banking supervision and reduce systemic risk in the financial sector.

\section{Policy considerations}

\section{The overall policy message}

The business environment will need to improve in support of private-sector development and growth. There is broad agreement, supported by business surveys, that weaknesses in the regulatory framework, capacity constraints and poor governance are constraining business opportunities and entrepreneurship. A proliferation of onerous regulations by local governments is also weighing on the business environment. This is despite recent efforts, including the latest policy packages for infrastructure and financial-sector development, as well as the enactment of the Investment Law in 2007, to strengthen the investment regime.

To be effective, policy action would need to be comprehensive and to create synergies among different policy areas. Consideration could therefore be given to initiatives aimed at strengthening the regulatory framework, including by removing red tape at the local level of government, improving governance and reducing remaining restrictions on foreign investment. This would be consistent with the APEC-OECD Integrated Checklist for Regulatory Reform. ${ }^{15}$ Further financial deepening would facilitate access by enterprises to more abundant, cheaper sources of finance.

\section{Improving the business climate}

There are options for curtailing the ability of local governments to introduce additional regulations and levies on business activity. Strong political resolve will be needed at the central government level to do so, given that local jurisdictions use this prerogative as a means of raising revenue. At a minimum, the central government could issue a list of business levies that would be deemed acceptable, subject to formal approval. The proposed levies could be collected only once approval has been granted. Any other instrument that might be introduced by the local governments would automatically be considered null and void. For these measures to be effective, it would be important to disseminate information on submissions and approvals broadly and transparently, preferably through the internet site of the Ministry of Home Affairs. At the same time, enforcement would need to be stepped up, because many such levies have been introduced without the accord of the central government.

15. See OECD (2005) for more information. 
Much can be done to facilitate compliance with business regulations. To this end, local governments that have not yet done so could be encouraged to set up one-stop shops (OSSs) in their jurisdictions. Currently only 284 of the 440 kota and kapubaten have such facilities in operation. This is despite the Minister of Home Affairs issuing regulations in July 2006 (Decree No. 24) instructing local governments to set up OSSs within a year. In addition, user satisfaction surveys could be carried out systematically, preferably by the central and local governments in conjunction with local business associations, to make sure that the budgetary resources devoted to these services are well spent and in line with the needs of the business community. This is important, because the range of services provided through OSSs varies significantly across local governments, and best practices can be learned and disseminated more effectively. Moreover, the use of information and communication technologies (ICTs) for the purpose of business registration could be encouraged. ${ }^{16}$ These efforts would also potentially reduce the scope of corruption, because face-to-face encounters would be replaced by on-line procedures, making it potentially more difficult for officials to solicit and/or be offered bribes in exchange for services.

The fight against corruption should continue. Recent efforts in this area are laudable. But specific sanctions could be introduced for different offenses. Co-ordination could also be stepped up among different layers of government in the areas of prevention and enforcement. In particular, while preventive efforts have already been made in many areas, they could be strengthened. This is the case, for example, of the requirement that civil servants submit personal wealth reports, because only $54 \%$ of senior government officials had done so by 2005, and only a small share of these reports have been audited. These reports could be made available to the public, which would contribute to enhancing transparency and accountability.

The legal system could be strengthened. The protection and enforcement of contracts would be a priority for improvement. Tangible results in this area would be important to attract foreign investment, particularly in sectors or activities that depend on transfers of new technologies and intellectual property in general. Allegations of discrimination against foreign companies in the court system remain a source of concern. More generally, there is a fairly general perception that the legal system is slow and imposes an additional cost on businesses.

\section{Attracting more and better FDI}

Consideration could be given to a further relaxation of remaining barriers to foreign investment. In particular, foreign-ownership constraints in selected sectors may have a detrimental impact on the quality of FDI. While intended to encourage technology transfers from multinationals, this requirement may in fact discourage such transfers, because foreign investors may be wary of losing intangible assets to local partners. This may be especially the case in technology-intensive sectors, such as fixed-line telephony, where foreign equity participation is capped at $49 \%$. Empirical evidence suggests that productivity tends to be higher in majority-owned foreign firms, once other standard determinants are taken into account. ${ }^{17}$ Also,

16. The experience of the Sragen district in Central Java is instructive. Sragen is the only local jurisdiction in the country currently offering one-stop services to have an ICT system in operation. The Integrated Service Agency was set up in 2002 to connect 20 district offices to the local government's headquarters. The system is expected to be expanded to 208 sub-districts and villages by the end of 2008 .

17. These hypotheses are by and large supported by empirical evidence. Productivity is higher in foreign-owned or controlled firms, once other determinants of productivity are taken into account (Thomsen, 1999; Takii and Ramstetter, 2005). By contrast, smaller multinationals are less prone to transfer technology from parent firms, so that their labour productivity levels are comparable to those of domestic firms. In addition, Blalock and Gertler (2008) find that technology transfers from multinationals to upstream firms lead to less concentration, lower prices and higher output growth in downstream firms. Borensztein et al. (1998) find that FDI crowds in domestic investment because of complementarities in production. For Indonesia, Blomström and Sjöholm (1999) find that labour productivity in domestic firms 
the findings reported in Annex A2 show that, together with the share of government-owned capital, foreign ownership increases enterprise spending on royalties, R\&D and human capital development.

There is some scope for strengthening the Investment Co-ordinating Board. To this end, the possibility of transferring the prerogative of appointing the Head of the Board to Parliament, rather than the executive branch of government (the President), as currently stated in the 2007 Investment Law, could be considered as a way of guaranteeing greater stability in investment policies.

The cost effectiveness of the tax incentives to be put in place in accordance with the new Investment Law will need to be assessed judiciously. The same applies to the tax expenditures associated with the new special economic zones that the government intends to create to boost economic activity, investment and employment in remote areas. ${ }^{18}$ There are many reasons to worry about cost effectiveness. On the one hand, tax incentives may be associated with deadweight losses, because they may benefit firms that would invest anyway, regardless of whether those incentives are available or not. On the other, by reducing the after-tax return on investment, such incentives divert savings to finance comparatively less profitable projects. In addition, the merits of sector-specific legislation, as opposed to across-the-board incentives that would not discriminate in favour of specific investments, would need to be taken into account in policy discussions. A final consideration is related to the reduction of import duties, which are currently restricted to capital goods, machinery and equipment that are not produced domestically. The possibility of broadening these incentives to imports that compete with locally produced capital goods and intermediate inputs could be evaluated as a means of fostering competition in these sectors.

Policy efforts to boost human capital accumulation would have the additional payoff of removing an obstacle to foreign investment in knowledge-intensive sectors. Studies show that technology transfers through FDI have been limited in Indonesia due to capacity constraints to absorb foreign technologies, including skills shortages. ${ }^{19}$ These weaknesses will need to be tackled, if Indonesia is to diversify its exports from primary and labour-intensive goods towards manufactured goods with higher value added. At the same time, efforts to develop infrastructure, especially in transport and telecommunications, would contribute to bolstering Indonesia's attractiveness to foreign investment in an environment of heightened competition for FDI, especially among regional peers.

\section{Removing infrastructure bottlenecks}

Intergovernmental fiscal relations need to be strengthened in support of public investment. An improved fiscal position has created, and will likely continue to create, room in the budget for increasing budgetary appropriations for investment projects in general and for infrastructure development in particular. At the same time, the alleviation of skills shortages at the local government level would remove existing constraints on the implementation of investment projects, as noted above. Policy co-ordination could also be enhanced among local governments in areas where inter-jurisdictional spillovers might

increases with foreign participation in the sector where these firms operate, suggesting the presence of intra-industry spillovers from FDI to domestically owned establishments.

18. The special economic zones envisaged by the government include not only the Batam, Bintan and Karimun islands near Singapore, but also Bali, Makassar and Bitung. The intention is to streamline administrative, tax and customs procedures to encourage investment in these regions.

19. Human capital facilitates technology transfers and enhances the capacity of local workers to assimilate foreign technology and know-how. See Borensztein et al. (1998) and Lim (2001) for more information. Agiomirgianakis et al. (2006) also find that, apart from human capital, infrastructure constitutes an important FDI attractor in the OECD area. Thomsen (1999) states that technology transfers from FDI have taken place mainly through on-the-job training and have been limited to basic skills in Indonesia. 
discourage individual action. Finally, a clarification of spending assignments across government levels would reduce uncertainty, which discourages local governments from investing.

The regulatory framework needs to be strengthened to remove obstacles to private-sector involvement in the electricity sector. The existence of price subsidies for fuel and electricity, despite cuts over the years, has had a detrimental impact on investment in the energy sector. Private-sector involvement is discouraged by price management, because it is difficult for investors to assess rates of return on projects, and by existing restrictions on equity ownership, discussed above. Decisive action is therefore needed to remove these obstacles if the authorities expect the private sector to be an important partner in infrastructure development. The design of a new regulatory framework would obviously be a complex task. But, at a minimum, it would include the liberalisation of prices and entry into the generation, transmission and distribution segments of the energy market and the introduction of an independent regulator in the sector. An increase in electricity supply would certainly have a significant effect on welfare for the poorer members of society. This is because they lack access to electricity, which makes it about six times more expensive for them to obtain energy compared to those who do have an electricity connection (LPEM-FEUI, 2003).

There are important challenges in the water/sanitation sector, where investment in infrastructure development is extremely low. As in the case of energy, the main obstacle to private-sector involvement is of a regulatory nature. Prices are set at unrealistically low levels, which do not allow for full cost recovery. The consequent financial losses imposed on the utility companies (PDAMs) have therefore curtailed their ability to invest. The option of liberalising prices and entry into the sector, as well as setting up an independent regulator, would be a much-needed first step towards encouraging private-sector investment. Again, the regulatory challenges associated with a comprehensive overhaul of the current system should not be underestimated.

\section{Promoting further financial deepening}

Indonesia fares poorly in conventional indicators of financial development, even in comparison with regional peers. This suggests that there is considerable scope for further financial deepening. Credit has expanded briskly in recent years, aided by favourable global financial conditions until recently, the strengthening of the banking sector after the financial crisis and a gradual reduction in real interest rates in an environment of continued disinflation. But more could to be done to encourage further credit growth in a manner that is consistent with financial resilience and the conduct of monetary policy under inflation targeting. Efforts in this area would go in the direction of unlocking additional sources of finance for investment by facilitating access to credit by the underserved population, especially poor individuals and SMEs, which often operate in the informal sector and have limited recoverable capital to be used as collateral for bank loans. Survey-based information shows that insufficient collateral is among the main reasons why firms are unable to borrow from formal financial institutions.

The merits of further consolidation in the banking sector could be re-evaluated. The Indonesian banking system is already fairly concentrated. The authorities are right that a multitude of small banks creates challenges for banking supervision. But the scope for further consolidation to boost efficiency through gains in economies of scale needs to be weighed against the risk that additional concentration might weaken competition among banks, which would most likely result in less favourable lending conditions for individuals and enterprises (OECD, 2001; Amel et al., 2004). The monetary authorities are advised to carefully assess these risks and to factor in the costs to the budget of the tax breaks that have been introduced to encourage mergers and acquisitions in the banking sector.

More could be done to reduce the presence of State-owned banks in the financial system. Of course, the rescue of financial institutions in distress after the 1997-98 crisis explains to a large extent the rise in 
the share of bank assets accounted for by State-owned banks. More generally, as in many other emerging-market economies in the OECD area and beyond, strong government involvement in the financial sector was originally justified by the need to correct market failures and to channel directed credit to selected economic sectors and activities. But, in a progressively more liberal economic environment, the case for continued government ownership of commercial banks becomes less compelling. The full privatisation of these banks could therefore be considered.

Initiatives to develop the non-bank sector would be welcome. The pension and mutual fund industry, as well as insurance, have benefitted from macroeconomic adjustment since the 1997-98 crisis, supportive global financial conditions and a reduction in interest rates in recent years. But existing regulatory barriers could be removed to foster further development in these market segments. These include regulatory barriers to entry in the insurance sector, which hamper competition. Foreign ownership in the insurance industry is capped at $80 \%$ by the 2007 Investment Law. This cap is perceived as overly stringent, because local companies often lack the capital for the remaining $20 \%$ needed to set up a joint venture with a foreign partner. Also, capital requirements are higher for entrants than for companies already operating in the market. This increases entry costs and gives a competitive advantage to incumbents. The possibility of increasing the equity ownership cap set by the Investment Law to the $99 \%$ level applicable to banks could be considered as a way of fostering the development of the non-bank sector. 


\section{Bibliography}

Agiomirgianakis, G.M., D. Asteriou and K. Papathoma (2006), "The Determinants of Foreign Direct Investment: A Panel Data Study for the OECD Countries", Working Paper, No. 3, City University, London.

APEC-OECD (2005), "Integrated Checklist on Regulatory Reform: A Policy Instrument for Regulatory Quality, Competition Policy and Market Openness", APEC-OECD Co-operative Initiative on Regulatory Reform, OECD, Paris.

Asian Development Bank (2003), "Country Governance Assessment Report, Republic of Indonesia", Asian Development Bank, Manila.

Asian Development Bank (2005), "Improving the Investment Climate in Indonesia", Asian Development Bank, Manila.

ATKearney (2005), “FDI Confidence Index 2005”, Global Business Policy Council, Alexandria, VA.

ATKearney (2007), “FDI Confidence Index 2007”, Global Business Policy Council, Alexandria, VA.

Bardhan, P. (1997), "Corruption and Development: A Review of Issues", Journal of Economic Literature, Vol. 3, pp. 1320-46.

BKPM (2007), "Statistics of Direct Investment. Monthly Report, October", Investment Co-ordinating Board, Jakarta.

Blalock, G. and P.J. Gertler (2008), "Welfare Gains from Foreign Direct Investment through Technology Transfer to Local Suppliers", Journal of International Economics, forthcoming.

Blomström, M. and F. Sjöholm (1999), "Technology Transfer and Spillovers: Does Local Participation with Multinationals Matter?", European Economic Review, Vol. 43, pp. 915-23.

Borensztein, E., J. de Gregorio and J.-W. Lee (1998), "How Does Foreign Direct Investment Affect Economic Growth?", Journal of International Economics, Vol. 35, pp. 115-35.

Calderon, C. and L. Serven (2004), "The Effects of Infrastructure Development on Growth and Income Distribution”, Policy Research Working Paper, No. 3400, World Bank, Washington, DC.

de Mello. L. and M. Barenstein (2001), "Fiscal Decentralisation and Governance: A Cross-Country Analysis", Working Paper, No. 01/71, International Monetary Fund, Washington, D.C.

Lim, E.-G. (2001), "Determinants of, and the Relation Between, Foreign Direct Investment and Growth: A Summary of the Recent Literature", Working Paper, No. 175, International Monetary Fund, Washington, D.C. 
LPEM-FEUI (2003), "Study on the Impact of Increases in the Fuel Price and Electricity Tariff", Joint report, Institute for Economic and Social Research, University of Indonesia, and Energy Analysis and Policy Office, USAID, Jakarta.

LPEM-FEUI (2005), "Inefficiency in the Logistics of Export Industries: The Case of Indonesia", Joint report, Institute for Economic and Social Research, University of Indonesia, and Japan Bank for International Cooperation, Jakarta.

LPEM-FEUI (2007a), "Investment Climate Monitoring. Round IV”, Institute for Economic and Social Research, University of Indonesia, Jakarta.

LPEM-FEUI (2007b), "Domestic Trade Barrier: The Case of Transportation Costs in Indonesia", Joint report, Institute for Economic and Social Research, University of Indonesia, World Bank and Asia Foundation, Jakarta.

Narjoko, D. and F. Jotso (2007), "Survey of Recent Developments", Bulletin of Indonesian Economic Studies, Vol. 43, pp. 143-69.

OECD (2006), “OECD's FDI Regulatory Restrictiveness Index: Revision and Extension to More Economies", Working Paper on International Investment, No. 2006/4, OECD, Paris.

Patunru, A.A., N. Nurridzki and Rivayani (2007), "Port Competitiveness: A Case Study of Semarang and Surabaya, Indonesia", in D. Brooks and D. Hummels (eds), Infrastructure's Role in Lowering Asia's Trade Costs: Building for Trade, Asian Development Bank, Manila.

Takii, S. and E.D. Ramstetter (2005), "Multinational Presence and Labour Productivity Differentials in Indonesian Manufacturing, 1975-2001", Bulletin of Indonesian Economic Studies, Vol.41, pp. 221-42.

Thomsen, S. (1999), "Southeast Asia: The Role of Foreign Direct Investment Policies in Development", OECD Directorate for Financial, Fiscal and Enterprise Affaires Working Paper, No. 1, OECD, Paris.

World Bank (2004), “Averting an Infrastructure Crisis: A Framework for Policy and Action”, The World Bank Office, Jakarta.

World Bank (2006a), "Revitalizing the Rural Economy: An Assessment of the Investment Climate Faced by Non-Farm Enterprises at the District Level", World Bank, Washington, D.C.

World Bank (2006b), “Unlocking Indonesia's Domestic Financial Resources”, World Bank, Washington, D.C.

World Bank (2007), "Spending for Development: Making the Most of Indonesia's New Opportunities. Indonesia Public Expenditure Review 2007”, World Bank, Washington, D.C. 


\section{Annex A1}

\section{Infrastructure investment and economic growth ${ }^{1}$}

This Annex uses principal component and co-integration analyses to assess the relationship between investment in infrastructure development and economic activity in Indonesia. If indicators of infrastructure development and GDP are found to co-integrate, at least one of them should adjust over time in response to movements in the other one to maintain a stable relationship between them. Once the existence of a stable relationship is established, the direction of causality is assessed.

\section{Measuring infrastructure development}

Information is not readily available on public and private expenditure on infrastructure development or on the value of a country's stock of infrastructure capital. Indonesia is no exception. In addition, emphasis on expenditure flows as a measure of infrastructure development would neglect the efficiency with which investment in infrastructural development are designed and implemented. The empirical analysis reported below therefore focuses on conventional output indicators, such as the coverage of a country's transport and telecommunications networks, as well as its energy generation and distribution capabilities. A focus on these three sectors is due to data availability.

Principal component analysis will be used to reduce the set of potential infrastructure output indicators to a tractable number of common factors. ${ }^{2}$ It is not possible to include all potentially relevant indicators in the estimating equation, because they far outnumber the degrees of freedom needed to obtain the relevant parameter estimates. Also, these indicators are highly collinear, which weakens their individual predictive power.

The indicators used to extract the principal components are available from the World Bank's World Development Indicators database. They cover quantity and quality indicators in three sectors: energy (indicators of total electricity production, shares of electricity production from hydropower and from oil, the extent of electric power transmission and distribution losses, electric power consumption, value of energy imports and use, volumes of combustible renewables and waste), transport (number of air transport passengers) and information and communications technology (number of fixed line and mobile phone subscribers, value of telecom investment and revenue, number of employees in the telecom sector, number of telecom mainlines and subscribers). Only the indicators for which information was available for at least 30 years (to maximise the number of observations) and which were found to be normally distributed were retained. The sample spans the period 1970-2006. The two components whose eigenvalues were found to explain nearly all the variation in the data were retained.

\section{Testing for unit roots and co-integration}

Real GDP, per capita GDP and the two factors computed on the basis of the principal component analysis were tested for the presence of unit roots using the ADF test. The results for the GDP series show

1. This Annex was prepared by Luiz de Mello.

2. Principal component analysis is useful in data reduction. It has been used in the empirical analysis of infrastructure and growth by Calderon and Serven (2004), among others. According to the technique, the leading eigenvectors from the eigen decomposition of the covariance matrix of the variables under consideration describe a series of uncorrelated linear combinations of those variables that contain most of the variance in the data. 
that the real GDP and per capita GDP series follow I(1) processes in levels (with or without a linear time trend). The results of the test carried out on the two infrastructure factors show that one of them (F1, defined in logarithmic form) follows an I(1) process in levels (with or without a linear time trend), whereas the other (F2) was found to be stationary in levels. F2 was therefore dropped from the analysis, since it cannot co-integrate with the GDP series.

The Johansen-Juselius test was performed on the levels of the GDP and F1 series. In this case, a system $X=(G D P, F 1)$ can be written in error-correction form as $A(L) \Delta X_{t}=\Pi X_{t-1}+u_{t}$, where, as usual $\Pi=\alpha \beta^{\prime}, \beta^{\prime}$ is the vector of co-integrating coefficients, $\alpha$ is the vector of loading coefficients, $A(L)$ is the distributed lag operator, and $u_{t}$ is a multivariate white-noise process. The results of the co-integration tests, reported in Table A1.1, show that there are at most one co-integrating vector on the basis of the trace and maximum eigenvalue statistics. Infrastructure is positively signed in the co-integrating vector (normalised on GDP), suggesting that a $1 \%$ improvement in the composite indicator of infrastructure is associated with an increase in GDP by nearly $0.9 \%$, regardless of whether GDP is defined in per capita terms or not. These high long-term returns would suggest that infrastructure is under-provided.

The results of the weak exogeneity tests are also reported in Table A1.1. The procedure consists of imposing a restriction on the loading parameters, such that the full hypothesis that the $i$-th row of $\alpha$ is zero can be tested. If the null hypothesis cannot be rejected, then the $i$-th endogenous variable is found to be weakly exogenous with respect to $\beta$. On the basis of this test, GDP was found to be weakly exogenous, but not the indicator of infrastructure development. These findings suggest that causality runs from GDP to infrastructure development in the long term, regardless of whether GDP is defined in per capita terms or not.

Table A1.1. Infrastructure development and economic activity: Co-integration tests, 1970-2006 ${ }^{1}$

(Dep. Vars.: Real GDP or Real GDP per capita and infrastructure, in logs)

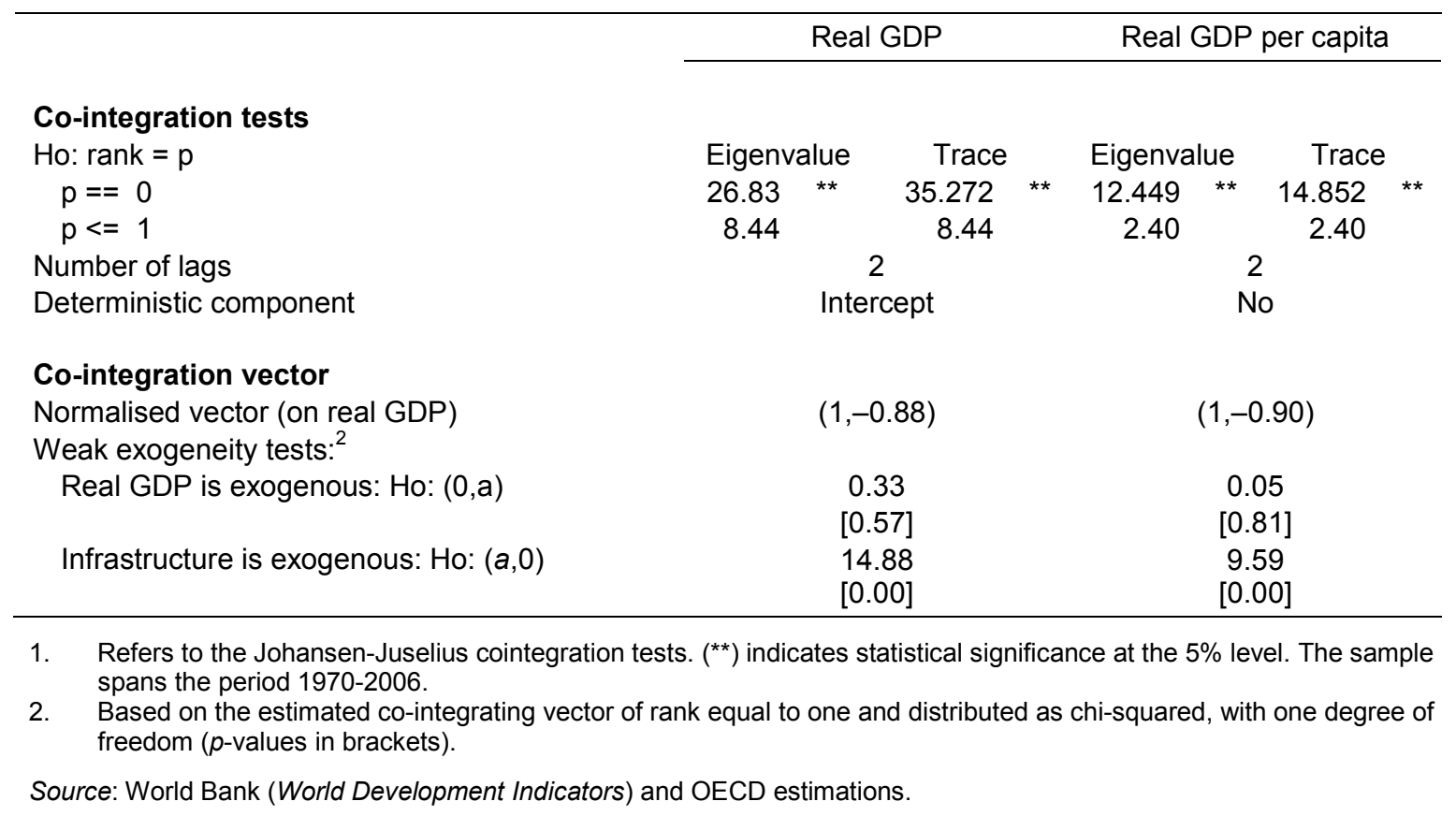




\section{Annex $A 2$}

\section{Enterprise expenditure on royalties, $R \& D$ and labour training: Firm-level evidence}

This Annex reports empirical evidence based on firm-level data on how capital structure affects enterprise expenditure on royalties, $\mathrm{R} \& \mathrm{D}$ and labour training. Data are available from the Statistik Industri Survey carried out by BPS on an annual basis. The Survey covers a large number of manufacturing establishments and provides detailed information on output, investment, capital, assets and expenditure, with a breakdown by production and nonproduction workers. The 1997 wave is used, because it features a special module on workers' educational attainment and enterprise expenditure on innovation.

\section{The regressions}

The determinants of firms' expenditure on royalties, R\&D and labour training (in 100000 rupiah) are estimated using the Tobit regression model. This is the appropriate econometric technique to use, because the dependent variable is censored, and linear estimation methods would lead to biased estimations. The independent variables are the share of capital owned by the government and by foreign investors (the omitted reference category is the share of capital owned by domestic firms), measures of enterprise size (value of capital and number of employees), the educational level of workers (proxied by the percentage of workers with at least tertiary education), location (province where the enterprise is located) and type of product. Errors are clustered at the provincial level to allow for the possibility that firms located in the same province have correlated disturbances.

\section{The results}

The results, reported in Table A2.1, show that enterprise expenditure on royalties, R\&D and labour training rises with the share of capital owned by the government and by foreign investors. Foreign ownership has a stronger impact on expenditure on royalties than government ownership. But the converse is true for expenditure on $\mathrm{R} \& \mathrm{D}$ and labour training.

Regarding the control variables, enterprise size (measured by both capital and number of employees) is positively associated with all three spending categories. The quality of human capital at the firm level is also positively associated with spending on royalties, $R \& D$ and labour training. This may be due to the fact that a more skilled labour force increases the rates of return on innovation and labour training. Finally, the significance of some of the product and provincial dummies confirms the existence of inter-sectoral and geographical disparities in the determinants on innovation and labour training. 
ECO/WKP(2008)46

Table A2.1. The determinants of expenditure on royalties, R\&D and labour training, $1997^{1}$

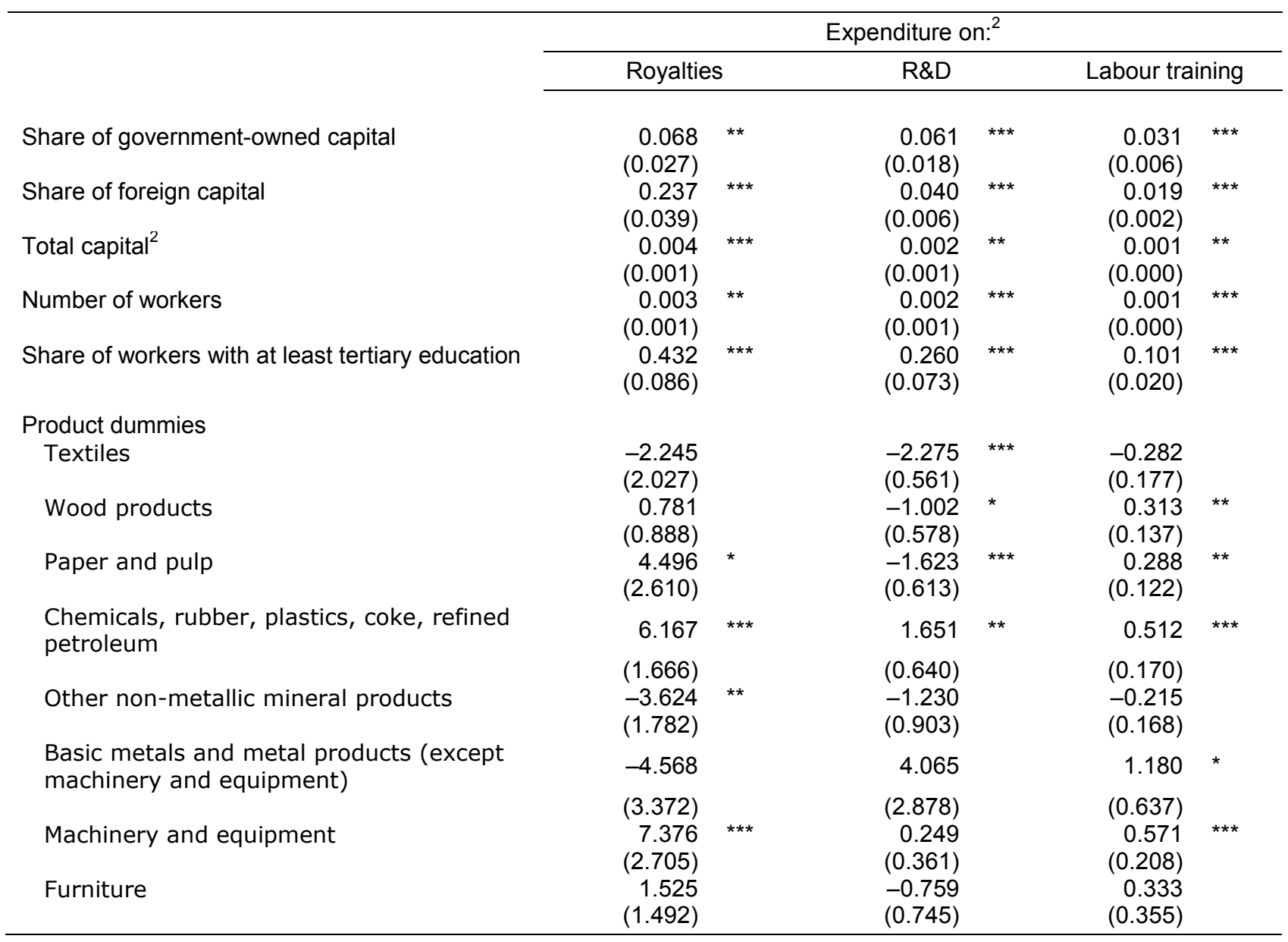

1. All regressions are estimated by Tobit and include provincial dummies (not reported). Statistical significance at the 1,5 and $10 \%$ levels is denoted by $\left({ }^{* * *}\right),\left({ }^{* *}\right)$ and $\left({ }^{*}\right)$, respectively. Robust standard errors clustered at the provincial level are reported in parentheses.

2. Defined in 100000 rupiah.

Source: Statistik Industri data and OECD estimations. 
ECO/WKP(2008)46

\section{WORKING PAPERS}

The full series of Economics Department Working Papers can be consulted at www.oecd.org/eco/Working_Papers/

637. Growth performance and policy challenges

(September 2008), Luiz de Mello

636 A taxonomy of instruments to reduce greenhouse gas emissions and their interactions (September 2008), Romain Duval

635 Quantifying the effect of financial conditions on US activity (September 2008) Stéphanie Guichard and David Turner

634. Have long-term financial trends changed the transmission of monetary policy (September 2008), Stéphanie Guichard and David Turner

633. Raising education achievement and breaking the cycle of inequality in the United Kingdom (August 2008) Anne-Marie Brook

632. The euro changeover in the Slovak Republic: implications for inflation and interest rates (August 2008) Felix Hüfner and Isabell Koske

631. Tax reform for efficiency and fairness in Canada (August 2008) Alexandra Bibbee

630. Reforming the Polish Tax System to Improve its Efficiency (August 2008) Alain de Serres

629. Modernising Canada's Agriculture Policies (August 2008) Peter Jarrett and Shuji Kobayakawa

628. Recent trends and structural breaks in US and EU15 labour productivity growth (August 2008) Laure Turner and Hervé Boulhol

627 Health Status Determinants: Lifestyle, Enviroment, Health Care Resources and Efficiency (August 2008) Isabelle Joumard, Christophe André, Chantal Nicq and Olivier Chatal

626. Market Mechanisms in Public Service Provision (August 2008) Hansjörg Blöchliger

625. Improving human capital formation in India (July 2008) Sean S. Dougherty and Richard Herd

624. Labour regulation and employment dynamics at the state level in India (July 2008) Sean S. Dougherty

623. India's growth pattern and obstacles to higher growth (July 2008) Sean S. Dougherthy, Richard. Herd, Thomas. Chalaux and Abdul. Erumban 
622. Reaping the benefits of stronger competition in network industries in Germany (July 2008) Nicola Brandt

621. The Usefulness of Output Gaps for Policy Analysis (July 2008) Isabell Koske and Nigel Pain

620. Taxation and Economic Growth (July 2008) Åsa Johansson, Christopher Heady, Jens Arnold, Bert Brys and Laura Vartia

619. Coping with labour shortages: How to bring outsiders back to the labour market (July 2008) Ekkehard Ernst

618. Achieving sustainability of the energy sector in Canada (June 2008) Annabelle Mourougane

617. The Dutch tax-benefit system and life-cycle employment. Outcomes and reform options (June 2008) Ekkehard Ernst and Timo Teuber

616. Regulation, Allocative Efficiency and Productivity in OECD Countries: Industry and Firm-Level Evidence

(May 2008) Jens Arnold, Giuseppe. Nicoletti, and Stefano Scarpetta

615. Public social spending in Korea in the context of rapid population ageing (May 2008) Randall S. Jones

614. Enhancing the globalisation of Korea (May 2008) Randall S. Jones and Taesik Yoon

613. Reforming housing and regional policies in Korea (May 2008) Randall S. Jones and Tadashi Yokoyama

612. Moving towards more sustainable healthcare financing in Germany (May 2008) N. Brandt

611. Improving education outcomes in Germany (May 2008) David Carey

610. Have developed countries escaped the curse of distance? (May 2008) Hervé Boulhol and Alain de Serres

609. Measures of international transport cost for OECD countries $\mid$ (April 2008) Stephen S. Golub and Brian Tomasik

608. Encouraging labour force participation in Chile (April 2008) D. Contreras, L. de Mello and E. Puentes

607. Tackling business and labour informality in Chile (April 2008) D. Contreras, L. de Mello and E. Puentes

606. Delivery cost-efficient public services in health care, education and housing in Chile (April 2008) D. Contreras, L. de Mello and E. Puentes 